https://doi.org/10.37208/tgn27207

\section{D.S. Raitt (1903-1944): a premature loss to Scottish fisheries research}

\author{
P.G. Moore \\ 32 Marine Parade, Millport, Isle of Cumbrae \\ KA28 0EF \\ E-mail: p.geoff.moore@gmail.com
}

Douglas Stewart Raitt (1903-1944) was born in Aberdeen on 18th January 1903, the son of John Raitt a chemical works manager, and educated at Robert Gordon's College, Aberdeen (Russell, 1945). A triple graduate of the University of Aberdeen (B.Sc. 1926; Ph.D. 1930; D.Sc. 1937), he married Jane Ferrier on 2nd November 1932 (Mackintosh, 1960). Before the Second World War, he served on the staff of the Marine Laboratory of the Fishery Board for Scotland, Aberdeen. He was elected a Fellow of the Linnean Society of London on 7th March 1935, his application supported by three influential signatories: William Thomas Calman FRSE, FRS (1871-1952), Stanley Wells Kemp FRS (1882-1945) and Isabella Gordon OBE (1901-1988). Elected a Fellow of the Royal Society of Edinburgh in 1936 he was appointed Buckland lecturer for 1940, although the outbreak of war prevented his delivery of the projected series of lectures on his specialist focus - the haddock (Melanogrammus aeglefinus) (Russell, 1945), and he was seconded to the Home Security Department and appointed assistant for the Highlands. Later, he went on to hold a similar post in the Edinburgh and South-east of Scotland area, ending-up as principal assistant to District Commissioner Sir John Phin (1881-1955) (Anonymous, 1944).

A man of many parts, he was also a writer of plays and songs. He wrote one of the productions of the University of Aberdeen Students' Gala weeks (Raitt, 1933a) - annual events featuring musical, theatrical and comedic elements held since 1921 . The 1933 show was re-written extensively and presented in its new form for a week in September 1934 to coincide with the third visit to Aberdeen of the British Association for the Advancement of Science. Raitt directed these shows in 1931, 1933-1934 and 1938-1939, and participated therein as "Rab the Rhymer." A popular performer, singing to his own piano accompaniment, he broadcast on the BBC from its Aberdeen studio.

Tragically he was fatally injured in an accident at his home, Thriepley House, Lundie, Angus on 4th October 1944 while attempting to start a car, when it moved off and ran over him (Anonymous, 1944). He left a wife and two children*. Russell (1945) averred that "all deplore that early death should have cut short the brilliant career opening before him." Marine science has been blighted by car accidents: Sir John Murray KCB, FRS (1841-1914) was killed when his motor car overturned near his home in Edinburgh, and Edward Flanders Robb "Ed" Ricketts (1897-1948) was killed when a passenger train hit his car in Monterey, California.

The haddock was central to Raitt's professional career. Curing haddock by smoking had become commonplace in Scotland by 1830 . Fish were split so as to lie flat, then smoked over a peat fire - a method that originated at Findon in Scotland and was widely copied (Gray, 1978). In Aberdeen such fish, smoked with turf, were called Finnan haddies, the product being taken by coach and sea to Edinburgh and Glasgow and by steamship to London. These and Arbroath smokies, another form of smoked haddock, remain a Scottish delicacy. Of course fresh haddock was consumed in Scotland and no small part in its promotion was played by immigrant Italians who opened fish-and-chip shops, first in Glasgow then in Edinburgh and elsewhere: between 1890 and 1914 their number increased from 750 to 4,500 (Coull, 2008).

Howell (1921) devoted a chapter in his book Ocean Research and the Great Fisheries to what he called "the haddock problem." He noted that "about 71.8 per cent of haddock came from the North Sea and they formed about 45.1 per cent of the North Sea catch in 1906." Between 1906 and 1913 there was a serious "decline" in North Sea haddock that may have been a result of natural fluctuations, something to which the species is prone (due to disparate numbers of juveniles entering the population in different years: Adams, 1996; Gulland, 1970), rather than the impact of steam trawling. Howell (1921) noted that the Norwegians had been collecting data bearing on the life-history of the species and felt that "British naturalists ought to be in close touch with all haddock investigations." Raitt's work on the bionomics of the North Sea haddock (Raitt, 1930, 1933b, 1936, 1937a, 1939) was therefore most apposite in investigating the biology of this species which by that time ranked alongside the herring as the most significant food-fish in Scotland (Adams, 1996). Haddock investigations had been initiated in Aberdeen by the then Scientific Superintendent (later Director) of the Marine Laboratory, $\mathrm{Dr}$ Alexander Bowman (1876-1941), and brilliantly executed by Dr Harold Thompson (1890-1957) (see references in Hardy, 1959). When Thompson left for Newfoundland, Raitt was given charge of the haddock work (Russell, 1944).

Supplementing his haddock researches, Raitt published two papers on amphipod crustaceans (Raitt, 1929, 1937b), both bearing on fishery issues. Benthic Amphipoda play an important role as a source of demersal fish food, indeed Raitt's 1937b paper was 
based partly on an analysis of haddock stomach contents and partly on benthic sampling using a Petersen grab. Raitt's 1929 paper, which confirmed earlier observations (Faulkner, 1925), referred to dead cod (Gadus morhua) with no outwards sign of infestation whose ovaries were being consumed by scavenging lysianassid amphipods Tmetonyx cicada; these appeared to have entered via the oviducts probably after the cod had died when bad weather delayed hauling of ground nets.

Away from haddock, as a side-line Raitt turned his attention to sandeels (Russell, 1944). The belief that there were only three species of sandeel in U.K. waters, viz. Hyperoplus lanceolatus, Ammodytes tobianus and Gymnammodytes semisquamatus, continued until 1934 when Raitt discovered a fourth, deeper-water, species named now after its discoverer as Raitt's sandeel (A. marinus) and known also as the small sandeel. (A fifth species, $H$. immaculatus, was discovered in 1950: see https://britishseafishing.co.uk/Greater-and-lessersandeel/).

I am grateful to Lynda Brooks (Linnean Society of London) and Helen McGregor (Marine Scotland Science) for information received.

*Raitt's son, Douglas Ferrier Stewart Raitt, born in 1935, followed in his father's footsteps as a fishery scientist, obtaining a Ph.D. for research on the norway pout (Trisopterus esmarkii) from the University of Aberdeen in 1967 and subsequently working at the Marine Laboratory, Aberdeen and at the Food and Agriculture Organisation in Rome.

\section{REFERENCES}

Adams, J.A. (1996). The Scottish contribution to marine science and fisheries research with particular reference to fisheries research during the period 1882-1939. British Marine Science and Meteorology: the History of their Development and Application to Marine Fishing Problems. Buckland Occasional Papers 2, 97-116.

Anonymous (1932). Wedding of Dr D.S. Raitt; Laurencekirk bride for popular BBC artist. Aberdeen Press and Journal 3rd November 1932, 3.

Anonymous (1944). Dr Raitt killed by car. Aberdeen Press and Journal 5th October 1944, 4.

Coull, J.R. (2008). The development of the marketing of fresh sea fish. In: Coull, J.R., Fenton, A. \& Veitch, K. (Editors). Scottish Life and Society: A Compendium of Scottish Ethnology, Boats, Fishing and the Sea, pp. 320-329. Birlinn Ltd., Edinburgh.

Faulkner, G.H. (1925). Amphipod crustaceans attacking cod ovary. The Scottish Naturalist 154, 131-132.

Gray, M. (1978). The Fishing Industries of Scotland 1790-1914: A study in Regional Adaptation. Oxford University Press, Oxford.

Gulland, J.A. (1970). Food chain studies and some problems in world fisheries. In: Steele, J.H. (Editor). Marine Food Chains, pp. 296-315. Oliver \& Boyd, Edinburgh.
Hardy, A. (1959). The Open Sea: Its Natural History. Part II: Fish and Fisheries. Collins, London.

Howell, G.C.L. (1921). Ocean Research and the Great Fisheries. Clarendon Press, Oxford. https://doi.org/10.5962/bhl.title.8283

Mackintosh, J. (1960). Roll of Graduates of the University of Aberdeen, 1926-1955; with Supplement 1860-1925. University of Aberdeen Press, Aberdeen.

Raitt, D.S. (1929). Cod roe attacked by amphipod crustaceans. The Scottish Naturalist 176, 57-58. https://doi.org/10.1016/S0033-3506(29)80036-4

Raitt, D.S. (1930). The Fecundity of Annual Egg Production of the Haddock (Gadus aeglefinus L.), with Special Reference to the Factors Determining or Influencing Same. Ph.D. thesis, University of Aberdeen, Aberdeen.

Raitt, D.S. (1933a). Town and Gown: A Medley of Fact and Fiction Concerning Aberdeen and its University. Aberdeen University Students Representative Council, Aberdeen.

Raitt, D.S. (1933b). The fecundity of the haddock. Scottish Fishery Investigations 1932, 1, 1-42.

Raitt, D.S. (1934). A preliminary account of the sandeels of Scottish waters. Journal du Conseil International pour L'exploration de la Mer 9, 365372. https://doi.org/10.1093/icesjms/9.3.365

Raitt, D.S. (1936). The haddock stocks of the northeast Atlantic, 1916-1935. Scientific Investigations, Fishery Board for Scotland, 1936, 1, 1-32.

Raitt, D.S. (1937a). Stock Replenishment, Fishing Intensity, Yield Prediction, and Ancillary Problems in Relation to the Haddock Stock of the North-east Atlantic. D.Sc. Thesis, University of Aberdeen.

Raitt, D.S. (1937b). The benthic Amphipoda of the north-western North Sea and adjacent waters. Proceedings of the Royal Society of Edinburgh 57, 241-254. https://doi.org/10.1017/S037016460001378X

Raitt, D.S. (1939). The rate of mortality of the haddock of the North Sea stock, 1919-1938. Rapports et Procès-verbeaux des Réunions du Conseil International pour L'exploration de la Mer 110, 6579.

Russell, E.S. (1945). Obituary. Douglas Raitt. Proceedings of the Linnean Society of London 156, 231-232. 